\title{
MENAKAR BATAS KESETARAAN GENDER \\ POLIGAMI DALAM PP. NO. 45 TAHUN 1990 \\ TENTANG IZIN PERKAWINAN DAN \\ PERCERAIAN BAGI PNS
}

\author{
Awaliah Musgamy \\ Fakultas Syariah dan Hukum Universitas Islam Negeri (UIN) Alauddin Makassar
}

\begin{abstract}
:
PP. Number. 45 in the Year 1990 the $4^{\text {Th }}$ article the $\left(2^{\text {nd }}\right)$ paragraph about the prohibition of female civil servant to be taken as the second/third/fourth wife of a man does not reflect gender equality because on the other PP. Number. 45 in the Year 1990 about Marriage and Divorce Licensed for Civil Servants generally allows male civil servants to do so as it can be identified in the the $4^{\text {Th }}$ article the $1^{\text {st }}$, the $2^{\text {nd }}$, and the $3^{\text {rd }}$ paragraph. The absence of gender equality as reflected in the PP. Number. 45 in the Year 1990 the $4^{\text {Th }}$ article the $\left(2^{\text {nd }}\right)$ brings about gender inequalities that denies the existence of men and women as beings that have been created with the rights and obligations of each. In relation to the limits of gender equality in the PP. Number. 45 in the Year 1990 about Marriage and Divorce Licensed for Civil Servants, both male and female civil servants, must have equal access to poligamy as long as they can fulfill strict and fair requirements.
\end{abstract}

\section{Keywords:}

Gender Equality, Poligamy, Civil Servant

\begin{abstract}
Abstrak:
PP. Nomor. 45 di Tahun 1990 pasal 4 ayat (2) tentang larangan pegawai negeri sipil untuk menjadikan sebagai istri kedua/ketiga/ keempat seorang pria tidak mencerminkan kesetaraan gender disebabkan PP yang lain. Jumlah. 45 pada Tahun 1990 tentang Perceraian dan Perceraian yang Berlisensi untuk Pegawai Negeri Sipil umumnya memungkinkan pegawai negeri sipil melakukannya karena dapat diidentifikasi dalam pasal 4Th ayat 1, 2, dan 3. Tidak adanya kesetaraan gender sebagaimana tercermin dalam PP. Nomor. 45 Tahun 1990 artikel ke-4 (2) menghasilkan ketidaksetaraan gender yang menyangkal keberadaan pria dan wanita sebagai makhluk yang telah diciptakan dengan hak dan kewajiban masing-masing. Sehubungan dengan batasan kesetaraan gender dalam PP. Nomor. 45 tahun 1990 tentang Perceraian dan Perceraian yang Berlisensi
\end{abstract}


untuk Pegawai Negeri Sipil, pegai negeri sipil laki-laki dan perempuan, harus memiliki akses yang sama terhadap poligami asal dapat memenuhi persyaratan yang ketat dan adil.

\section{Kata Kunci:}

Kesetaraan Gender, Poligami, Pegawai Negeri Sipil

\section{A. PENDAHULUAN}

ajian tentang larangan dipoligami bagi PNS wanita tidak bisa dipisahkan
dari tidak bisa dipisahkan dari berbagai aspek yang melingkupi praktik
poligami itu sendiri yang salah satunya adalah aspek historisnya. Sayyid Sabiq menggambarkan bahwa poligami telah dipraktikkan oleh berbagai bangsa seperti Arab, Ibrani, Cisilia, dan yang lainnya sebelum kedatangan Islam. ${ }^{1} \mathrm{Di}$ samping rekam historis tersebut, poligami juga telah terakomodir setelah kedatangan agama Islam dengan adanya landasan normatif dalam Q.S. an-Nisa (04):3-4 yaitu:

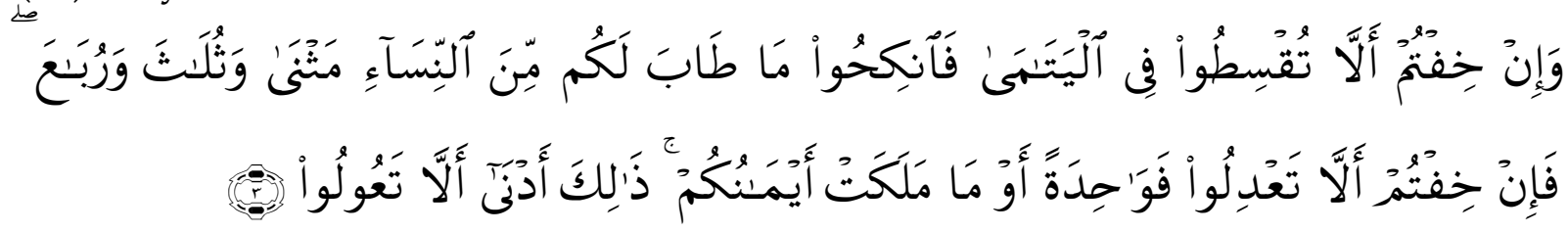

Terjemahnya:

Dan jika kamu takut tidak akan dapat berlaku adil terhadap (hak-hak) perempuan yang yatim (bilamana kamu mengawininya), maka kawinilah wanita-wanita (lain) yang kamu senangi: dua, tiga atau empat. Kemudian jika kamu takut tidak akan dapat berlaku adil, maka (kawinilah) seorang saja, atau budak-budak yang kamu miliki. yang demikian itu adalah lebih dekat kepada tidak berbuat aniaya. ${ }^{2}$

Meskipun poligami telah menjadi suatu fenomena yang menghiasi kehidupan manusia dalam lintasan sejarah serta telah mendapat landasan normatif dari alQur'an, ${ }^{3}$ poligami masih menyisakan perdebatan yang hangat di kalangan masyarakat Islam termasuk yang ada di Indonesia dimana poligami menjadi isu dalam perkawinan yang paling banyak dibicarakan sekaligus kontroversial. ${ }^{4}$ Dalam perspektif penulis, munculnya perdebatan yang menyikapi praktik poligami tersebut tidak terlepas dari berbagai fenomena tarik menarik dua pihak yang mendukung

${ }^{1}$ Sayyid Sabiq, Fikih Sunnah, Jilid III, diterjemahkan oleh Nor Hasanuddin, (Jakarta: Pena Pundi Aksara, 2007), h. 9

${ }^{2}$ Q.S. an-Nisa (04):3-4

${ }^{3}$ Obsesi al-Qur'an adalah terwujudnya keadilan dalam masyarakat. Al-Qur'an tidak mentolelir segala bentuk penindasan baik berdasarkan kelompok etnis, warna kulit, suku bangsa, kepercayaan, termasuk jenis kelamin. Nasaruddin Umar, Argumen Kesetaraan Gender Perspektif al-Qur'an, (Jakarta: Paramadina, 1999), h. 265

${ }^{4}$ Amir Nuruddin dan Azhar Akmal Tarigan, Hukum Perdata Islam di Indonesia, (Jakarta: PT. Prenada Media Group, 2006), h. 156 
dan menolak poligami itu sendiri. Pihak yang mendukung praktik poligami menganggap bahwa poligami sebagai salah satu solusi dalam meminimalisir perselingkuhan, prostitusi, dan berbagai penyakit masyarakat lainnya. Sementara pihak yang menolaknya dilandasi dengan pertimbangan bahwa poligami adalah praktik yang kemudian mendudukkan wanita pada posisi yang terjajah dalam rumah tangga baik secara fisik ataupun psikis. Sebagai sintesa dari kedua pihak tersebut, muncul pihak yang ketiga yang menerima praktik poligami dengan persyaratan-persyaratan yang ketat.

Dalam konteks ke-Indonesiaan, khususnya bagi mereka yang berstatus PNS, terlihat bahwa poligami disikapi sebagai sesuatu diterima dengan persyaratanpersyaratan yang ketat seperti yang dapat ditemukan pada PP.No.10 Tahun 1983 yang telah dirubah dengan PP.No.45 Tahun 1990 tentang Ijin Perkawinan dan perceraian bagi Pegawai Negeri Sipil. Hal yang menarik kemudian untuk dicermati adalah pada isi PP.No.45 Tahun 1990 tersebut hanya PNS wanita yang tidak diperbolehkan untuk terlibat dalam praktik poligami sebagaimana termaktub dalam pasal 4 ayat (2) sementara PNS pria tetap diperbolehkan meskipun dengan persyaratan yang cukup ketat. Oleh karena itu, penulis tertarik untuk mengupas PP.No.45 Tahun 1990 tentang Ijin Perkawinan dan Perceraian bagi Pegawai Negeri Sipil untuk menakar batas kesetaraan gender antara pria dan wanita di dalamnya agar tergambar sebuah keadilan gender yang bisa memposisikan kaum pria dan kaum wanita pada hubungan horizontal-subordinatif dan bukan pada hubungan vertikal-kordinatif.

\section{B. PEMBAHASAN}

\section{Kerangka Kesetaraan Gender dalam Islam}

Dalam upaya menyingkap kerangka kesetaraan gender antara pria dan wanita, yang harus dipahami adalah bagaimana membedakan konsep jenis kelamin dan konsep gender itu sendiri. Pemahaman akan perbedaan dari kedua konsep tersebut dapat berimplikasi pada kearifan dan kebijaksanaan dalam menyikapi berbagai persoalan ketidakadilan sosial yang menimpa kaum wanita di berbagai belahan dunia. Hal ini tentunya didasari oleh asumsi bahwa ada hubungan yang cukup erat antara perbedaan gender (gender differeces) dan ketidakadilan gender (gender inequalities) dengan struktur ketidakadilan sosial secara umum. Pemahaman atas konsep gender sangat diperlukan mengingat dari konsep tersebut lahir suatu analisis gender. ${ }^{5}$

Idealnya, perbedaan gender tidak perlu berimplikasi pada ketidakadilan gender tapi realitas menunjukkan bahwa perbedaan gender tersebut telah diekspolitasi besar-besaran sebagai alasan untuk melakukan hegemononi terstruktur kepada kaum wanita dalam berimplikasi pada beberapa hal seperti marginalisasi

\footnotetext{
${ }^{5}$ Mansour Fakih, Analisis Gender dan Transformasi Sosial, (Yogyakarta: Pustaka Pelajar, 1997), h. 4
} 
wanita, penempatan perempuan pada subordinasi, stereotype wanita, kekerasan pada wanita, beban kerja yang tidak proporsional. ${ }^{6}$ Berbagai fenomena ketidakadilan sosial tersebut tentunya sangat merugikan kaum wanita sebagai kaum yang diposisikan sebagai kaum yang lemah dan hubungannya dengan kaum pria berada pada poros yang sifatnya vertikal-kordinatif.

Menyikapi hal tersebut, Umi Sumbulah menyatakan bahwa hubungan antara pria dan wanita dalam lingkup perdebatan tentang kesetaraan gender telah melahirkan tiga teori yaitu teori nature, teori nurture, serta teori equilibrium. Teori nature didorong oleh teori biologi dan teori fungsionalisme struktural yang menyatakan bahwa perbedaan peran gender bersumber dari perbedaan biologi pria dan wanita sementara teori nurture yang didorong oleh teori konflik dan feminisme menyatakan bahwa perbedaan gender antara pria dan wanita bukan merupakan konsekuensi dari perbedaan biologis yang kodrati namun tidak lebih dari sebuah hasil konstruksi manusia yang sangat bergantung pada kondisi sosio-kultural yang melingkupinya. ${ }^{7}$ Secara sepintas, terlihat bahwa kedua teori di atas saling bertolak belakang satu sama lain dimana teori nature memahami fenomena gender sebagai sesuatu yang sudah terkonstruk sejak manusia dilahirkan berdasarkan jenis kelamin yang dimilikinya sementara teori nurture melihat bahwa fenomena gender merupakan sebuah konstruk sosial yang bisa saja sengaja dimunculkan atas nama hegemoni jenis kelamin tertentu atas yang lainnya meskipun kemudian wanita yang lebih banyak diposisikan sebagai kelompok yang dirugikan.

Sebagai sintesa dari benturan dua teori di atas, teori equilibrium muncul untuk membentuk kemitraan antara pria dan wanita dalam bingkai kesetaraan gender. Konsekuensinya, teori equilibrium tidak mempertentangkan perbedaan jenis kelamin antara pria dan wanita karena keduanya memang harus bekerjasama. ${ }^{8} \mathrm{Hal}$ ini mengisyaratkan bahwa perbedaan jenis kelamin bukanlah sebuah alasan untuk mendudukkan mereka pada posisi yang saling berlawanan satu sama lain tapi sebaliknya keduanya harus didudukkan dalam posisi sebagai mitra yang harus saling mengisi satu sama lain. Fakta empiris membuktikan bahwa ada yang bisa dilakukan oleh pria tapi tidak bisa dilakukan oleh wanita karena kodrat atau kemampuannya yang tidak memungkinkan tapi kebalikannya ada juga sesuatu yang bisa dilakukan oleh wanita tapi tidak bisa dilakukan oleh pria karena kodrat atau kemampuannya yang juga tidak memungkinkan. Disinilah perlunya sebuah kemitraan di antara keduanya untuk saling mengisi satu sama lain dalam bingkai kesetaraan gender.

Sementara itu, Zaenul Mahmudi menyatakan bahwa kesetaraan gender dapat dilihat pada informasi-informasi yang ada dalam al-Qur'an dan hadits tentang

\footnotetext{
${ }^{6}$ Mufidah, Paradigma Gender, (Malang: Bayumedia Publishing, 2004), h. 90

${ }^{7}$ Umi Sumbulah, Spektrum Gender: Kilauan Inklusi Gender di Perguruan Tinggi, (Malang: UIN Malang Press, 2008), h. 27

8 Purwieningrum E, Gender dan Permasalahannya, http://hqweb01.bkkbn.go.id. (Diakses pada 13 Oktober 2015)
} 
konsep pria dan wanita dalam arti biologis sebagai manusia yang memiliki penis dan vagina (physical genital) dan konsep pria dan wanita dalam arti sosiologis dan budaya (cultural genital). ${ }^{9}$ Hal itu mengisyarat bahwa menyikapi persoalan gender tidak sesederhana menilai seseorang berdasarkan dimensi fisiknya saja tapi juga persoalan gender juga mencakup sisi sosiologis dan budaya yang tentunya yang disikapi dengan lebih komprehensif.

Beberapa isyarat normatif dari al-Qur'an yang mengisyaratkan kesetaraan gender dapat ditemukan pada ayat-ayat berikut:

1. Q.S. al-Hujurat (49): 13

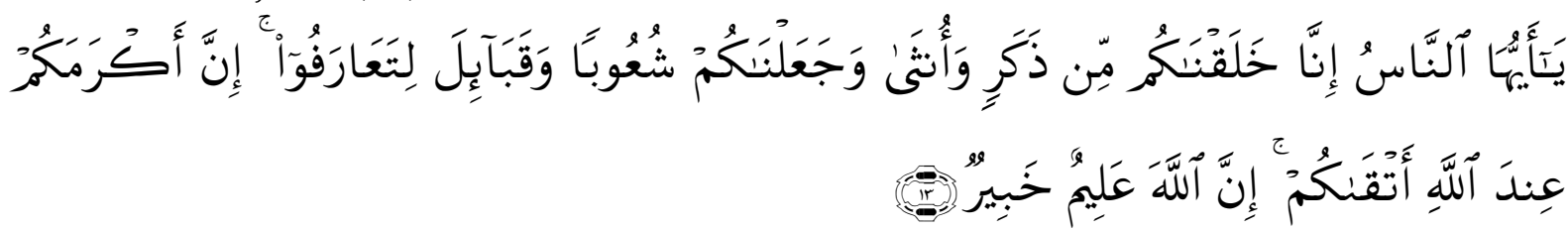

Terjemahnya:

Hai manusia, sesungguhnya kami menciptakan kamu dari seorang laki-laki dan seorang perempuan dan menjadikan kamu berbangsa-bangsa dan bersuku-suku supaya kamu saling kenal-mengenal. Sesungguhnya orang yang paling mulia diantara kamu disisi Allah ialah orang yang paling taqwa diantara kamu. Sesungguhnya Allah Maha Mengetahui lagi Maha Mengenal. ${ }^{10}$

2. Q.S. an-Nisa (04): 1

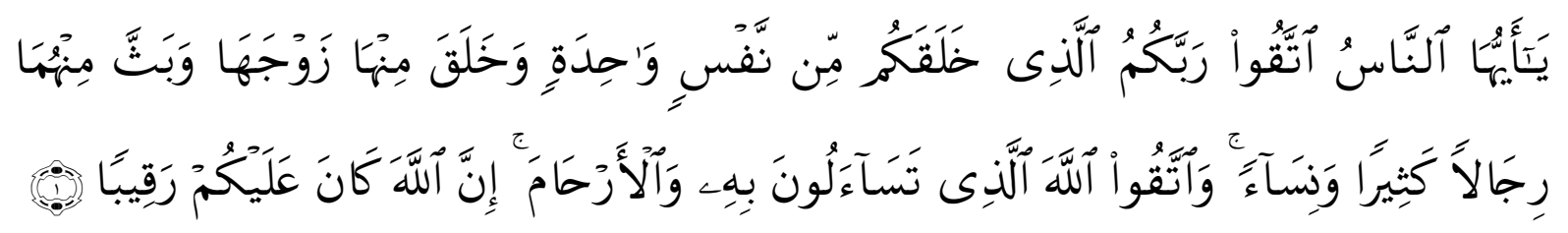

Terjemahnya:

Hai sekalian manusia, bertakwalah kepada Tuhan-mu yang telah menciptakan kamu dari seorang diri, dan dari padanya Allah menciptakan isterinya; dan dari pada keduanya Allah memperkembangbiakkan laki-laki dan perempuan yang banyak. Dan bertakwalah kepada Allah yang dengan (mempergunakan) nama-Nya kamu saling meminta satu sama lain, dan (peliharalah) hubungan silaturrahim. Sesungguhnya Allah selalu menjaga dan mengawasi kamu. ${ }^{11}$

3. Q.S. an-Nisa (04): 32

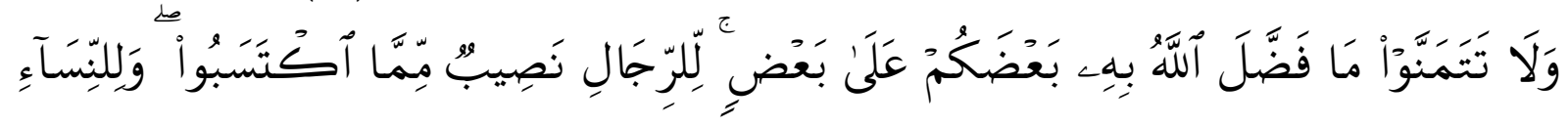

${ }^{9}$ Zaenul Mahmudi, Sosiologi Fikih Perempuan: Formulasi Dialektis Fikih Perempuan dengan Kondisi Sosial dalam Pandangan Imam Syafi'i, (Malang: UIN Malang Press, 2009), h. 69

${ }^{10}$ Q.S. al-Hujurat (49) : 13

${ }^{11}$ Q.S. an-Nisa (04) : 1 


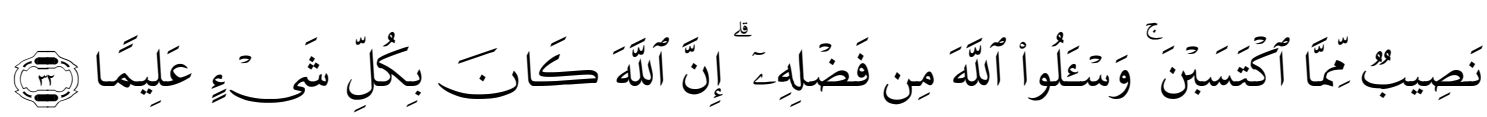

Terjemahnya:

Dan janganlah kamu iri hati terhadap apa yang dikaruniakan Allah kepada sebahagian kamu lebih banyak dari sebahagian yang lain. (Karena) bagi orang laki-laki ada bahagian dari pada apa yang mereka usahakan, dan bagi para wanita (pun) ada bahagian dari apa yang mereka usahakan, dan mohonlah kepada Allah sebagian dari karunia-Nya. Sesungguhnya Allah Maha mengetahui segala sesuatu. ${ }^{12}$

Beberapa isyarat normatif dari al-Qur'an yang mengisyaratkan kesetaraan gender tersebut $\mathrm{d}$ atas menggambarkan bahwa pria dan wanita memiliki kesetaraan gender di mata Allah Swt. dalam berbagai dimensinya seperti dalam hal penciptaannya, kodratnya dalam perkembangbiakan umat manusia, kelebihan dan kekurangan masing-masing yang saling mengisi, dan semacamnya.

\section{PP. No. 45 Tahun 1990 tentang Izin Perkawinan dan Perceraian bagi PNS}

Produk hukum UU No.1 Tahun 1974 tentang perkawinan dan peraturan pelaksanaannya yaitu PP No.9 Tahun 1975 berlaku untuk semua warga Indonesia. Untuk PNS, selain kedua produk hukum tersebut, mereka juga diharuskan tunduk pada PP.No.10 Tahun 1983 Jo. PP No. 45 Tahun 1990 tentang izin perkawinan dan perceraian bagi PNS. Hal ini tentunya membawa sebuah isyarat psiko-yuridis bahwa PNS harus memberikan teladan yang baik bagi yang bukan PNS sebagai warga negara yang baik dalam membina kehidupan bermasyarakat. Di samping itu, PP tersebut secara tidak langsung memperketat dan mempersulit izin perceraian dan poligami. ${ }^{13}$

Dalam PP. No.45 Tahun 1990 yang menganut asas monogami, telah diatur dengan jelas alasan boleh atau tidaknya seorang PNS pria untuk beristri lebih dari satu dan tidak bolehnya tidaknya PNS wanita untuk menjadi istri kedua/ketiga/keempat. Hal ini mengisyaratkan bahwa seorang PNS pria masih memungkinkan untuk beristri lebih dari satu orang sementara bagi PNS wanita memang tidak diperbolehkan sama sekali menjadi istri kedua/ketiga/keempat.

Hal di atas termaktub dalam PP. No.45 Tahun 1990 tentang Izin Perkawinan dan Perceraian bagi PNS pasal 4 sebagai berikut:

1. Pegawai Negeri Sipil pria yang akan beristri lebih dari seorang wajib memperoleh izin terlebih dahulu dari pejabat

2. Pegawai Negeri Sipil wanita tidak diizinkan untuk menjadi istri kedua/ketiga/keempat

3. Permintaan izin sebagaimana dimaksud dalam ayat (1) diajukan secara tertulis

4. Dalam surat permintaan izin sebagaimana dimaksud dalam ayat (3) harus dicantumkan alasan yang lengkap yang mendasari permintaan izin untuk

\footnotetext{
${ }^{12}$ Q.S. an-Nisa (04) : 32

${ }^{13}$ Setiawan Budi Utomo, Fiqih Aktual, (Jakarta: Gema Insani Press, 2003), h. 266.
} 
beristri lebih dari seorang.

Dalam pasal 4 ayat (2) telah ditegaskan dengan jelas bahwa PNS wanita tidak diizinkan untuk menjadi istri kedua/ketiga/keempat. Konsekuensinya, apabila ada PNS wanita yang tidak mematuhi aturan tersebut dengan menjadi istri kedua/ketiga/keempat dari seorang pria, PP. No. 53 Tahun 2010 tentang Disiplin Pegawai Negeri Sipil telah mengatur dengan jelas apa-apa yang bisa dilakukan dan tidak boleh dilakukan oleh seorang PNS. Dengan redaksi yang sangat jelas, PP. No.45 Tahun 1990 tentang Izin Perkawinan dan Perceraian bagi PNS pasal 15 ayat (2) menyatakan:

"Pegawai Negeri Sipil wanita yang melanggar ketentuan pasal 4 ayat (2) dijatuhi hukuman disiplin pemberhentian dengan tidak hormat sebagai Pegawai Negeri Sipil"14

Sanksi disiplin merupakan penerapan disiplin setelah adanya kejadian dikarenakan cara preventif tidak bisa dilakukan. Sanksi disiplin diberikan pada PNS yang melanggar sehingga PNS yang lain tidak meniru dan yang bersangkutan akan jera dan insyaf.

Adapun bagi PNS pria, PP. No.45 Tahun 1990 pasal 4 ayat (1) memberikan jalan bagi PNS pria untuk beristri lebih dari seorang dengan memberikan persyaratan yaitu adanya izin terlebuh dahulu dari pejabat yang dalam pasal 4 ayat (3) digambarkan bahwa izin yang diberikan tersebut harus dalam bentuk izin tertulis. Sebagai pertimbangan bagi pejabat yang ingin memberikan izin bagi PNS pria untuk bisa beristri lebih dari seorang, wanita yang menjadi istri pertamanya dianggap tidak mampu melaksanakan tugasnya sebagai istri, tidak bisa memberikan keturunan dan berbagai alasan lainnya yang dianggap bisa menjadi pertimbangan bagi pejabat untuk memberikan izin yang tetap harus mempertimbangkan sisi keadilan tentunya.

\section{Menakar Batas Kesetaraan Gender Poligami dalam PP. No. 45 Tahun 1990 tentang Izin Perkawinan dan Perceraian bagi PNS}

Mengacu pada PP. No.45 Tahun 1990 tentang Izin Perkawinan dan Perceraian bagi PNS, tergambar bahwa aturan poligami bagi PNS dalam kontes ke-Indonesiaan masih menunjukkan ketidakadilan gender dimana aspek-aspek kesetaraan gender menjadi terabaikan. Hal tersebut tergambar pada pasal 4 ayat (1) yang berbunyi "Pegawai Negeri Sipil pria yang akan beristri lebih dari seorang wajib memperoleh izin terlebih dahulu dari pejabat" sementara pasal 4 ayat (2) yang berbunyi "Pegawai Negeri Sipil wanita tidak diizinkan untuk menjadi istri kedua/ketiga/keempat">. Landasan yuridis tersebut tentunya menggambarkan bahwa PNS perempuan tidak diperbolehkan untuk menjadi istri kedua/ketiga/keempat sementara PNS pria diperbeolehkan untuk beristri lebih dari seorang.

${ }^{14}$ Peraturan Pemerintah Nomor 45 Tahun 1990 tentang Izin Perkawinan dan Perceraian bagi Pegawai Negeri Sipil 
Dalam perspektif teologis normatif sebagaimana yang terkandung dalam Q.S.

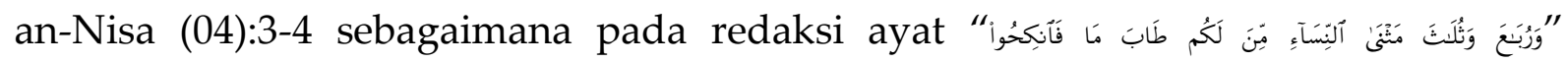
tergambar bahwa pria dan wanita masing-masing memiliki akses yang membolehkan mereka dalam praktik poligami baik pria yang memiliki istri lebih dari seorang demikian pula wanita yang bisa menjadi istri kedua/ketiga/keempat. Hanya saja, hal yang menarik kemudian untuk dicermati adalah bagaimana menakar kesetaraan gender antara PNS pria dan PNS wanita dalam PP. No.45 Tahun 1990 tersebut. Secara sepintas terlihat adanya suatu ketidakadilan gender dalam PP. No.45 Tahun 1990 tentang Izin Perkawinan dan Perceraian bagi PNS tersebut dimana hanya PNS pria saja yang diperbolehkan untuk melakukan praktik poligami sementara PNS wanita tidak diperbolehkan bahkan diikuti dengan ancaman pemberhentian dengan tidak hormat bagi yang melanggarnya sebagaimana termaktub dalam dalam PP. No.45 Tahun 1990 tentang Izin Perkawinan dan Perceraian bagi PNS pasal 15 ayat (2).

Pada dasarnya, PNS wanita boleh dijadikan sebagai istri kedua/ketiga/keempat karena memang landasan normatif teologis dari poligami membolehkannya akan tetapi landasan normatif yuridis tidak memperbolehkannya maka PNS wanita kemudian harus mengikuti aturan tersebut termasuk menerima konsekuensikonsekuensi yuridis apabila melanggarnya. Berbeda dengan PNS pria yang diperbolehkan untuk melakukan praktik poligami dengan memiliki istri lebih dari seorang meskioun dengan persyaratan-persyaratan yang ketat. Apabila kemudian yang menjadi pertimbangan tidak diperbolehkannya PNS wanita menjadi istri kedua/ketiga/keempat adalah karena pertimbangan harkat dan martabatnya sebagai seorang abdi negara lalu bagaimana dengan PNS pria yang melakukan praktik poligami dengan memiliki istri lebih dari seorang, harkat dan martabat mereka sebagai abdi negara pasti juga akan rusak sebagaimana yang terjadi pada PNS wanita, apabila kemudian yang menjadi pertimbangan bahwa bahwa apabila PNS wanita menjadi istri kedua/ketiga/keempat maka hal itu bisa mengganggu konsentrasinya sebagai seorang abdi negara karena rumah tangga yang didalamnya ada praktik poligami cenderung mengalami banyak percekcokan, maka pertanyaannya kemudian adalah bagaimana dengan PNS pria yang melakukan praktik poligami dengan memiliki istri lebih dari seorang, bisa dipastikan bahwa rumah tangga mereka juga tidak akan jauh dari percekcokan.

Kedua ilustrasi di atas adalah sebuah standar minimalis dalam melihat praktik poligami di kalangan PNS, baik pria ataupun wanita, meskipun kemudian fakta di lapangan juga ada yang membuktikan bahwa rumah tangga yang melakukan praktik poligami justru memberikan efek positif bagi keduanya, suami istri, dalam menjalankan fungsi masing-masing dalam bingkai kesetaraan gender. Poligami pada dasarnya bukanlah sesuatu yang harus diperdebatkan tapi harus didiskusikan karena ibarat pisau bermata dua, kadang-kadang poligami memberikan efek positif dan kadang-kadang memberikan efek negatif. Hal inilah yang telah diisyaratkan 
oleh Dedi Kusmayadi menyatakan bahwa poligami dengan syarat-syarat yang ketat jauh lebih manusiawi dibandingkan dengan melarang poligami itu sendiri yang bisa berakibat pada penyaluran hasrat seksual bukan pada tempatnya sehingga melarang ataupun menyembunyikan poligami bukanlah hal yang bijak tapi yang mesti harus dilakukan adalah membuka ruang diskusi untuk menakar kesetaraan gender yang pastinnya akan berimplikasi pada keadilan gender. ${ }^{15}$

Dalam kaitannya dengan penerapan syarat-syarat yang ketat bagi mereka yang akan melakukan poligami maka PP. No.45 Tahun 1990 tentang Izin Perkawinan dan Perceraian bagi PNS yang telah memberikan jalan bagi PNS pria untuk melakukan praktik poligami dengan berbagai syarat juga seharusnya memberikan akses bagi PNS wanita untuk menjadi istri kedua/ketiga/keempat dengan berbagai syarat yang ketat juga tentunya. Sebaliknya, apabila PNS wanita tidak diperbolehkan untuk terlibat dalam praktik poligami dengan menjadi istri kedua/ketiga/keempat dengan berbagai pertimbangan, maka PNS pria juga tidak diperbolehkan untuk melakukan praktik poligami dengan memiliki istri lebih dari seorang dengan mengacu pada berbagai pertimbangan itu pula.

Dalam analisis yang lebih komprehensif, dapat dipahami bahwa PNS wanita yang menjadi istri kedua/ketiga/keempat jauh lebih layak dibandingkan dengan wanita non-PNS untuk berada pada posisi sebagai istri kedua/ketiga/keempat. Pertimbangannya adalah PNS wanita dari sisi perekonomian sudah bisa dikatakan mapan dibandingkan dengan wanita non-PNS. Kalaupun kemudian ada yang membantah asumsi tersebut dengan mengatakan bahwa banyak juga wanita nonPNS yang lebih mapan seperti yang bekerja pada dunai bisnis misalnya, maka keraguan tersebut bisa terbantahkan dengan eksistensi PNS wanita sebagai orang yang lebih matang dari sisi intelektualnya. Bisa dibayangkan apabila ada sebuah keluarga dengan sepasang suami istri dan anak-anaknya yang kurang mampu dari sisi ekonomi kemudian ada seorang PNS wanita yang rela menjadi istri kedua dari kepala rumah tangga tersebut dengan didorong semangat untuk mengangkat level kehidupan keluarga tersebut menjadi keluarga yang mampu. Asumsi ini muncul dari apa yang selama ini digaung-gaungkan oleh kaum pria untuk melakukan praktek poligami termasuk apa yang telah dicontohkan oleh Rasulullah Saw. Di samping itu, membatasi akses PNS wanita pada praktik poligami dengan menjadi istri kedua/ketiga/keempat bisa membuat mereka melakukan perkawinan bawah tangan (nikah sirri) yang tentu saja kurang menjamin kepastian hukum dari perkawinan tersebut termasuk anak yang nantinya dilahirkan karena tidak tercatatnya perkawinan tersebut. Oleh karena itu, PP. No.45 Tahun 1990 tentang Izin Perkawinan dan Perceraian bagi PNS harus mempertimbangkan berbagai pertimbangan dan realitas tersebut untuk memberikan akses bagi PNS pria dan wanita untuk terlibat dalam praktik poligami atau justru menutup akses bagi

\footnotetext{
${ }^{15}$ Dedi Kusmayadi, Memilih Poligami Mempertimbangkan Anak, (Jakarta: Fajar, 2002), h. 4
} 
keduanya dengan pertimbangan kesetaraan gender meskipun penulis lebih cenderung pada opsi yang pertama yaitu membuka akses bagi keduanya meskipun dengan persyaratan-persyaratan yang ketat dan adil.

\section{KESIMPULAN}

PP. No.45 Tahun 1990 tentang Izin Perkawinan dan Perceraian bagi PNS dan yang lebih khusus yaitu pada pasal 4 ayat (2) yang membatasi PNS wanita untuk menjadi istri kedua/ketiga/keempat tidak mencerminkan kesetaraan gender karena pada sisi lain membolehkan PNS pria untuk melakukannya. Tidak adanya kesetaraan gender tersebut telah berimplikasi pada ketidakadilan gender yang menafikan eksistensi pria dan wanita sebagai makhluk yang telah diciptakan dengan hak dan kewajiban masing-masing. Dalam kaitannya dengan batas kesetaraan gender poligami dalam PP. No.45 Tahun 1990 tentang Izin Perkawinan dan Perceraian bagi PNS, baik PNS pria ataupun wanita, harus mendapatkan akses yang sama pada praktik poligami dalam hal boleh atau tidak bolehnya disertai dengan syarat-syarat yang ketat dan adil.

\section{Daftar Pustaka}

Fakih, Mansour, Analisis Gender dan Transformasi Sosial, Yogyakarta: Pustaka Pelajar, 1997.

Kusmayadi, Dedi, Memilih Poligami Mempertimbangkan Anak, Jakarta: Fajar, 2002.

Mahmudi, Zaenul, Sosiologi Fikih Perempuan: Formulasi Dialektis Fikih Perempuan dengan Kondisi Sosial dalam Pandangan Imam Syafi'i, Malang: UIN Malang Press, 2009.

Mufidah, Paradigma Gender, Malang: Bayumedia Publishing, 2004.

Nuruddin, Amir dan Azhar Akmal Tarigan, Hukum Perdata Islam di Indonesia, Jakarta: PT. Prenada Media Group, 2006.

Sabiq, Sayyid, Fikih Sunnah, Jilid III, diterjemahkan oleh Nor Hasanuddin, Jakarta: Pena Pundi Aksara, 2007.

Sumbulah, Umi, Spektrum Gender: Kilauan Inklusi Gender di Perguruan Tinggi, Malang: UIN Malang Press, 2008.

Umar, Nasaruddin, Argumen Kesetaraan Gender Perspektif al-Qur'an, Jakarta: Paramadina, 1999.

Utomo, Setiawan Budi, Fiqih Aktual, Jakarta: Gema Insani Press, 2003.

Peraturan Pemerintah Nomor 45 Tahun 1990 tentang Izin Perkawinan dan Perceraian bagi Pegawai Negeri Sipil

Purwieningrum E, Gender dan Permasalahannya, http://hqweb01.bkkbn.go.id. (Diakses pada 13 Oktober 2015) 